\title{
Survival of Cultured Neurons from Amyloid Precursor Protein Knock-Out Mice against Alzheimer's Amyloid- $\beta$ Toxicity and Oxidative Stress
}

\author{
Anthony R. White, ${ }^{1}$ Hui Zheng, ${ }^{2}$ Denise Galatis, ${ }^{1}$ Fran Maher, ${ }^{1}$ Lars Hesse, ${ }^{3}$ Gerd Multhaup, ${ }^{3}$ Konrad \\ Beyreuther, ${ }^{3}$ Colin L. Masters, ${ }^{1}$ and Roberto Cappai ${ }^{1}$ \\ ${ }^{1}$ Department of Pathology, The University of Melbourne and The Mental Health Research Institute, Parkville, Victoria, \\ Australia, 3052, 2Department of Genetics and Molecular Biology, Merck Research Laboratories, Rahway, New Jersey \\ 07065, and ${ }^{3}$ Center of Molecular Biology, The University of Heidelberg, 69120 Heidelberg, Germany
}

Studies on the amyloid precursor protein (APP) have suggested that it may be neuroprotective against amyloid- $\beta(A \beta)$ toxicity and oxidative stress. However, these findings have been obtained from either transfection of cell lines and mice that overexpress human APP isoforms or pretreatment of APPexpressing primary neurons with exogenous soluble APP. The neuroprotective role of endogenously expressed APP in neurons exposed to $A \beta$ or oxidative stress has not been determined. This was investigated using primary cortical and cerebellar neuronal cultures established from APP knock-out $\left(\mathrm{APP}^{-/-}\right.$) and wild-type (APP ${ }^{+/+}$) mice. Differences in susceptibility to $A \beta$ toxicity or oxidative stress were not found between $\mathrm{APP}^{-/-}$and $\mathrm{APP}^{+/+}$neurons. This observation may reflect the expression of the amyloid precursor-like proteins 1 and 2
(APLP1 and APLP2) molecules and supports the theory that APP and the APLPs may have similar functional activities. Increased expression of cell-associated APLP2, but not APLP1, was detected in $\mathrm{A} \beta$-treated $\mathrm{APP}^{-/-}$and $\mathrm{APP}{ }^{+/+}$cultures but not in $\mathrm{H}_{2} \mathrm{O}_{2}$-treated cultures. This suggests that the $A \beta$ toxicity pathway differs from other general forms of oxidative stress. These findings show that $A \beta$ toxicity does not require an interaction of the $A \beta$ peptide with the parental molecule (APP) and is therefore distinct from prion protein neurotoxicity that is dependent on the expression of the parental cellular prion protein.

Key words: Aß25-35; cortical neurons; neurotoxicity; APP; Alzheimer's disease; knock-out mice
An Alzheimer's disease (AD) brain contains numerous plaques composed of the amyloid- $\beta(\mathrm{A} \beta)$ amyloid peptide ( $\beta \mathrm{A} 4)$, which is derived from the proteolytic processing of the amyloid precursor protein (APP) (Glenner and Wong, 1984; Masters et al., 1985; Kang et al., 1987). APP is a transmembrane glycoprotein that undergoes extensive alternative splicing (Sandbrink et al., 1994). The APP751 and -770 isoforms contain a Kunitz-type protease inhibitor domain (Tanzi et al., 1988), whereas APP695, which lacks this domain, is expressed at high levels in CNS neurons (Koo et al., 1990). APP is processed by endoproteases called secretases. Constitutive cleavage within the $\mathrm{A} \beta$ domain by $\alpha$-secretase results in the generation of secreted $\operatorname{APP}(\operatorname{sAPP} \alpha)$. Alternatively, APP can be cleaved by $\beta$ - and $\gamma$-secretases to generate A $\beta$ (for review, see Mattson, 1997). APP is one of a multigene family that contains at least two other homologs known as amyloid precursor-like proteins 1 and 2 (APLP1 and APLP2) (Wasco et al., 1992; Sprecher et al., 1993; Slunt et al., 1994). The APLPs contain most of the domains and motifs of APP, including a hydrophobic membrane-spanning domain, $N$-glycosylation sites, copper and zinc binding domains, and the KPI domain (only APLP2). Neither APLP1 nor APLP2 contains the A $\beta$ region and cannot directly contribute to $\mathrm{A} \beta$ deposition in Alzheimer's dis-

\footnotetext{
Received Jan. 30, 1998; revised May 29, 1998; accepted June 8, 1998.

This work was supported in part by grants from the National Health and Medical Research Council of Australia to C.L.M. K.B. is supported by the Deutshe Forschungsgemeinschaft and the Bundesministerium fur Forschung und Technologie.

Correspondence should be addressed to Dr. Roberto Cappai, Department of Pathology, The University of Melbourne, Parkville Victoria 3052, Australia. Copyright (C) 1998 Society for Neuroscience $0270-6474 / 98 / 186207-11 \$ 05.00 / 0$
}

ease. The similarities between APP and APLP (particularly APLP2) suggest that the APLPs could share and compensate for the function of APP.

A number of activities for neuronal APP have been identified. In vitro studies suggest that membrane-associated and secreted APP have an important role in promoting cell-substratum adhesion, neurite extension and development, and synaptic function in neurons (Schubert et al., 1989; Milward et al., 1992; Salvietti et al., 1996). In addition to a neuritogenic role, APP may also have a neuroprotective effect. Neurotrophic factors and neuronal injury upregulate APP expression and induce secretion of sAPP (Nakamura et al., 1992; Mattson et al., 1993b; Ohyagi and Tabira, 1993; Schubert and Behl, 1993). The addition of sAPP to culture medium protects cortical and hippocampal neurons from neurotoxic insults induced by hypoglycemia and excitotoxic amino acids. It is believed that SAPP acts by stabilizing intracellular $\mathrm{Ca}^{2+}$ levels and reducing oxidative stress (Mattson et al., 1993b; Goodman and Mattson, 1994; Barger et al., 1995). Transfecting human cDNA into cell lines and transgenic mice can result in protection against oxidative stress and increased resistance to excitotoxicity (Schubert and Behl, 1993; Mucke et al., 1996). However, increased ischemic brain damage has been reported in transgenic mice that overexpress APP (Zhang et al., 1997). The pathways involved in these effects are yet to be determined.

The neuroprotective role of sAPP may also extend to $\mathrm{A} \beta$ toxicity. The $\mathrm{A} \beta$ peptides $(\mathrm{A} \beta 1-40$ and $\mathrm{A} \beta 1-42)$ can be toxic in vitro to a wide variety of neuronal cell types through disruption of $\mathrm{Ca}^{2+}$ homeostasis and increased oxidative stress (Yankner et al., 1989, 1990; Roher et al., 1991; Mattson et al., 1993a; Pike et al., 
1993). In addition, $\mathrm{A} \beta$ can potentiate excitotoxic, hypoglycemic, and oxidative damage to neurons (Koh et al., 1990; Lockhart et al., 1994). Treatment of rat hippocampal neurons with sAPP results in a protective effect against $\mathrm{A} \beta$ toxicity (Goodman and Mattson, 1994) by reducing $\mathrm{Ca}^{2+}$ influx and levels of reactive oxygen species. Similarly, it was shown that when the B103 neuronal cell line was transfected with human APP695 or APP751 it was significantly more resistant to $\mathrm{A} \beta$ toxicity compared with controls (Schubert and Behl, 1993). The increased survival of APP-expressing cells may reflect a heightened resistance to oxidative stress.

These studies indicate a role for APP in antioxidant responses. In $\mathrm{AD}$, the aberrant processing of APP may not only result in increased deposition of toxic $\mathrm{A} \beta$ but could also reduce the normal protective function of sAPP. At present, there are no published studies investigating the role of endogenous APP expression with respect to toxicity in neuronal cells. To determine whether endogenous APP expression alters the response to oxidative stress in neurons, we have established primary neuronal cultures from APP knock-out $\left(\mathrm{APP}^{-/-}\right)$and wild-type $\left(\mathrm{APP}^{+/+}\right)$mice and exposed them to toxic $A \beta$ peptide and different oxidative stresses. In contrast to previous experiments with exogenous sAPP or transfected cell lines, our study did not identify differences in cell survival in $\mathrm{APP}^{-/-}$compared with $\mathrm{APP}^{+/+}$neurons when both were exposed to various oxidative insults. This result may reflect expression of the APLP molecules that were detected in the neuronal cultures. Because of their close homology, the APLPs may have a function similar to that of APP and hence possess the ability to compensate for the absence of APP.

\section{MATERIALS AND METHODS}

Materials. Poly-L-lysine, 3,[4,5 dimethylthiazol-2-yl]-2,5 diphenyltetrazolium bromide (MTT), cytosine arabinofuranoside (Ara C), basic FGF (bFGF), xanthine oxidase, phenylmethylsulfonyl fluoride (PMSF), and protease inhibitors were purchased from Sigma (St. Louis, MO). Glutamine, glutamate, glucose, and gentamycin sulfate were obtained from Life Technologies (Gaithersburg, MD). A $\beta 25-35$ was obtained from Auspep Pty. Ltd. A $\beta 1-42$ was a gift from Dr. Ashley Bush (Massachusetts General Hospital, Boston). Fetal calf serum (FCS) and horse serum (HS) were from the Commonwealth Serum Laboratories. Xanthine was obtained from Boehringer Ingelheim. For immunoblotting, 22C11 (antiAPP/APLP2) was obtained from Boehringer Ingelheim. 25104 (antiAPLP1) is a rabbit polyclonal antiserum raised to an unconjugated peptide corresponding to APLP1 amino acids 499-557 (Paliga et al., 1997); 95/11 (anti-APLP2) is a rabbit polyclonal antiserum raised to recombinant APLP2 amino acids 28-693 (Wasco et al., 1993) expressed in Pichia pastoris (see below).

Primary neuronal cultures. The generation of the $\mathrm{APP}^{-1-}$ mice has been described previously (Zheng et al., 1995). Control mice (C57BL6J $\times 129 / \mathrm{Sv}$ ) correspond to genetically matched mice from which the $\mathrm{APP}^{-1-}$ mice were derived. Primary neuronal cultures of cerebral cortex and cerebellum were established from $\mathrm{APP}^{-/-}$and APP ${ }^{+/+}$mice. Cortices from embryonic day 14 (E14) and cerebella from postnatal day 5-6 (P5-6) mice were removed, dissected free of meninges, and dissociated in $0.025 \%$ trypsin. Cortical cells were plated onto poly-L-lysine $(5 \mu \mathrm{g} /$ $\mathrm{ml}$ )-coated 24-well plates (Greiner) at a density of $450,000 \mathrm{cells} / \mathrm{cm}^{2}$ (high density) or 250,000 cells $/ \mathrm{cm}^{2}$ (low density) in MEM (Life Technologies) supplemented with $10 \%$ FCS, $10 \%$ HS, 2 mM glutamine, $25 \mathrm{~mm}$ $\mathrm{KCl}$, and $5 \mathrm{gm} / 1$ glucose. Cerebellar granule neurons (CGNs) were plated on identical plates at 350,000 cells $/ \mathrm{cm}^{2}$ in BME (Life Technologies) supplemented with $10 \%$ FCS, $2 \mathrm{~mm}$ glutamine, and $25 \mathrm{~mm} \mathrm{KCl}$. Gentamycin sulfate $(100 \mu \mathrm{g} / \mathrm{ml})$ was added to all plating media, and cultures were maintained at $37^{\circ} \mathrm{C}$ in $5 \% \mathrm{CO}_{2}$. For lactate dehydrogenase (LDH) assays and some MTT assays, cortical cultures were placed in MEM with N2 supplements (Life Technologies) at day 3 in vitro. Ara C $(10 \mu \mathrm{M})$ was added at day 1 (CGN cultures) or day 6 (cortical cultures). Where stated, bFGF $(10 \mathrm{ng} / \mathrm{ml})$ was added to cultures at day 1 in vitro. Neuronal purity of cultures was $\sim 90-95 \%$ for cortical cultures and $96-98 \%$ for the cerebellar granule cell cultures.
Measurement of neuronal cell viability and cell death. Cell viability or redox potential was determined using the MTT assay. Culture medium was replaced with $0.6 \mathrm{mg} / \mathrm{ml}$ MTT in control salt solution (Locke's buffer containing $154 \mathrm{~mm} \mathrm{NaCl}, 5.6 \mathrm{~mm} \mathrm{KCl}, 2.3 \mathrm{mM} \mathrm{CaCl}_{2}, 1.0 \mathrm{mM} \mathrm{MgCl}_{2}, 3.6$ $\mathrm{mm} \mathrm{NaHCO}_{3}, 5 \mathrm{~mm}$ HEPES, and $5.6 \mathrm{~mm}$ glucose, $\mathrm{pH}$ 7.4) for $2 \mathrm{hr}$. The MTT was removed and cells were solubilized with dimethyl sulfoxide. Aliquots $(100 \mu \mathrm{l})$ were measured with a spectrophotometer at $570 \mathrm{~nm}$. Cell death was determined from culture supernatants free of serum and cell debris using an LDH Cytotoxicity Detection Kit (Boehringer Ingelheim) according to manufacturer's instructions. All cell survival assays were performed with the MTT assay unless stated otherwise.

Induction of oxidative stress. A $\beta 25-35$ was prepared as a $1 \mathrm{~mm}$ stock solution in $\mathrm{dH}_{2} \mathrm{O}$ and aged for $2-3 \mathrm{~d}$ at $37^{\circ} \mathrm{C}$. $\mathrm{A} \beta 1-42$ was prepared by dissolving the peptide in $\mathrm{dH}_{2} \mathrm{O}$, sonicating, and centrifuging for $5 \mathrm{~min}$ in a microfuge. The supernatant was adjusted to $200 \mu \mathrm{M}$ and added to cultures. After $3 \mathrm{~d}$ in culture, neuronal cells were exposed to $A \beta 25-35$ or A $\beta 1-42$. Neuronal redox activity and cell death were determined after $4 \mathrm{~d}$ of exposure to the peptide using the MTT and LDH assays, respectively.

Intracellular peroxide-associated oxidative stress was induced by addition of glutamate to immature cortical cultures (day 3 in vitro) for $24 \mathrm{hr}$. Extracellular peroxide toxicity was induced in cortical cultures by adding $\mathrm{H}_{2} \mathrm{O}_{2}$ to culture media for $24 \mathrm{hr}$ at day 4 in vitro. Superoxide anion production was generated in cell culture medium at days 4 and 6 in vitro by adding $50 \mu \mathrm{M}$ xanthine and increasing concentrations of xanthine oxidase to culture wells for $24 \mathrm{hr}$. Hypoglycemia was induced by washing cultures twice with glucose-free Locke's buffer followed by incubation in Locke's without glucose (5.6 mM, pH 7.4). Data represent the SEM of experiments performed in three to four cultures measured in triplicate.

Recombinant APP, APLP1, and APLP2. Recombinant secreted APP751, APLP2, and APLP1 were produced in the methylotrophic yeast Pichia pastoris. APP751 has been described previously (Henry et al., 1997). APLP2 was amplified by the PCR as a 1998 base pair DNA fragment corresponding to residues 28-693 of human APLP2. Human APLP2 cDNA (Wasco et al., 1993) was used as the PCR template (gift of Dr. Wilma Wasco, Massachusetts Institute of Technology, Cambridge, MA). The oligonucleotides used were CCG AAT TCT TGG CGC TGG CCG GCT ACA and CCC CTC TAG AAC TGC TAC TCA GAC TGA AGT C. The PCR fragment was digested with EcoRI and XbaI and ligated into EcoRI/XbaI-digested pIC9 (Invitrogen, San Diego, CA). Human $A P L P 1$, corresponding to amino acids $34-650$, was amplified by PCR with the primers AAG CTT ACG TAC AGC CCG CCA TCG GGA GCC TG and GGC AGC GGA AGG GCA CAA C. The PCR fragment was digested with SnaB I and ScaI and cloned into pIC9. The protein was expressed in the GS115 strain as described previously (Henry et al., 1997).

Quantitative immunoblotting of APP, APLP1, and APLP2. Cortical cultures (day 2 or 3 in vitro) were exposed to A $\beta 25-35(10 \mu \mathrm{M})$ or $\mathrm{H}_{2} \mathrm{O}_{2}$ $(25 \mu \mathrm{M})$ for $24 \mathrm{hr}$ and then homogenized in TES buffer $(20 \mathrm{mM}$ Tris, $\mathrm{pH}$ 7.4, $1 \mathrm{~mm}$ EDTA, $0.25 \mathrm{~m}$ sucrose) and the protease inhibitors pepstatin, aprotinin, and leupeptin at $10 \mu \mathrm{g} / \mathrm{ml}$ and $0.1 \mathrm{~mm}$ PMSF. Protein determination was performed using a BCA assay kit (Pierce, Rockford, IL), and normalized protein samples were separated on a $12 \%$ SDS-PAGE gel $(25 \mu \mathrm{g} /$ lane $)$ at $30 \mathrm{~mA} / \mathrm{gel}$. Separated proteins were transferred to PVDF membrane overnight, blocked overnight in $0.5 \%$ hydrolyzed casein, and probed for $1 \mathrm{hr}$ at room temperature (RT) with 22C11 (1:2000), $25104(1: 1000)$, or 95/11 (1:1000) in Tris-buffered saline (TBST) $(10 \mathrm{~mm}$ Tris, $0.9 \% \mathrm{NaCl}$, and $0.1 \%$ Tween-20, $\mathrm{pH} 7.5$ ). A secondary antibody [1:2000, rabbit anti-mouse immunoglobulins (Amersham, Arlington Heights, IL)] was applied to the 22C11-probed membrane for $1 \mathrm{hr}$ at RT. Blots were then probed with ${ }^{125} \mathrm{I}$-protein-A (Amersham) for $1 \mathrm{hr}$ at RT $(0.1 \mu \mathrm{Ci} / \mathrm{ml}$ in $0.5 \%$ casein $)$. Blots were washed three times ( $10 \mathrm{~min}$ each) between each probing step with TBST, $\mathrm{pH}$ 8.5. Blots were analyzed and quantitated on a Fujix BAS 1000 Phosphorimager using MacBas1 software.

\section{RESULTS APP $^{-/-}$neuronal cell cultures}

To determine whether there were differences in basal cell survival in neurons from $\mathrm{APP}^{-/-}$and $\mathrm{APP}^{+/+}$mice, we established primary cortical and cerebellar neuronal cultures from mice at E14 and P5, respectively. As shown in Table 1, growth of APP ${ }^{-1-}$ cortical neurons in serum-containing media (up to $7 \mathrm{~d}$ ) or in 


\begin{tabular}{|c|c|c|c|c|}
\hline \multirow[b]{3}{*}{ Days in vitro } & \multirow{3}{*}{$\begin{array}{l}\text { Media } \\
\text { supplement }\end{array}$} & \multicolumn{3}{|c|}{$\%$ Survival compared with $\mathrm{APP}^{+/+}$neurons } \\
\hline & & High density & Low density & \multirow[b]{2}{*}{ Cerebellar } \\
\hline & & Cortical & & \\
\hline 1 & Serum & $101 \pm 5$ & $103 \pm 7$ & $102 \pm 2$ \\
\hline 3 & Serum & $101 \pm 5$ & $98 \pm 4$ & $101 \pm 1$ \\
\hline 7 & Serum & $100 \pm 1$ & $97 \pm 5$ & $99 \pm 3$ \\
\hline 7 & $\mathrm{~N} 2$ & $104 \pm 4$ & $102 \pm 4$ & $\mathrm{ND}^{a}$ \\
\hline 14 & $\mathrm{~N} 2$ & $105 \pm 2$ & $108 \pm 3$ & $97 \pm 5$ \\
\hline
\end{tabular}

Primary cortical neurons were grown at high $\left(450,000\right.$ cells $\left./ \mathrm{cm}^{2}\right)$ and low $\left(250,000 \mathrm{cells} / \mathrm{cm}^{2}\right)$ density in MEM supplemented with $10 \% \mathrm{FCS}$ and $10 \% \mathrm{HS}$ for up to $7 \mathrm{~d}$ or in MEM and N2 from day 3 to day 14 in vitro. Primary cerebellar granule neurons were grown in BME with $10 \%$ FCS for up to $7 \mathrm{~d}$ in vitro and in $\mathrm{N} 2$ for up to $14 \mathrm{~d}$.

${ }^{a} \mathrm{ND}$, Not done.

serum-free N2-supplemented media (up to $14 \mathrm{~d}$ ) showed no significant difference in cell survival compared with $\mathrm{APP}^{+/+}$ neurons. The growth of cerebellar neurons in serum-containing media also revealed no differences between $\mathrm{APP}^{-1-}$ and wildtype mice. We conclude that growth and survival of primary neuronal cultures at high or low density, with and without serum (after day 3 in vitro) does not differ significantly between $\mathrm{APP}^{-1-}$ and $\mathrm{APP}^{+/+}$neurons under basal conditions.

\section{A $\beta 25-35$ and $A \beta 1-42$ toxicity in $\mathrm{APP}^{-/-}$and $\mathrm{APP}^{+/+}$ cortical neuronal cultures}

To determine whether the APP molecule is directly involved in neuronal responses to $\mathrm{A} \beta$ peptide-mediated toxicity, we added $\mathrm{A} \beta 25-35$ or $\mathrm{A} \beta 1-42$ peptide to 3-d-old cultures of $\mathrm{APP}^{-1-}$ and APP ${ }^{+/+}$cortical neurons. The $\mathrm{A} \beta 25-35$ peptide was aged at $37^{\circ} \mathrm{C}$ for 2-3 d in $\mathrm{dH}_{2} \mathrm{O}$ and showed considerable fibril formation (data not shown). The A $\beta 1-42$ peptide also produced considerable fibril formation when prepared as described in Materials and Methods. Cultures were assayed for neuronal redox activity using the MTT assay after exposure for $4 \mathrm{~d}$ to $\mathrm{A} \beta$ peptides at different concentrations. The intracellular reduction of MTT to insoluble product is rapidly and significantly inhibited in many types of neurons treated with $\mathrm{A} \beta$ peptides (Abe and Kimura, 1996). With this treatment regimen, $0.5 \mu \mathrm{M} \mathrm{A} \beta 25-35$ induced a significant decline in MTT reduction compared with non-A $\beta$-treated control cultures (Fig. $1 A$ ). Increasing concentrations of $\mathrm{A} \beta$ resulted in a further loss of MTT reduction up to $25 \mu \mathrm{M} \mathrm{A} \beta$, the highest concentration used. A significant difference was not observed in MTT reduction between $\mathrm{APP}^{-/-}$and $\mathrm{APP}^{+/+}$cortical cultures (Fig. 1A). Because APP expression and resistance to oxidative stress could be affected by cell density, low-density $(250,000$ cells $/ \mathrm{cm}^{2}$ ) primary cortical neuronal cultures were also established and exposed to $A \beta 25-35$. Measurement of cell viability after exposure for $4 \mathrm{~d}$ revealed no difference between $\mathrm{APP}^{-/-}$ and $\mathrm{APP}^{+/+}$cultures (Fig. $1 B$ ). Similar results were obtained when cultures were exposed to $A \beta 1-42$. No significant difference was observed in MTT readings between $\mathrm{APP}^{-/-}$and $\mathrm{APP}^{+/+}$ neurons after $4 \mathrm{~d}$ exposure to 5 or $20 \mu \mathrm{M} \mathrm{A} \beta 1-42$ (Fig. $1 C$ ).

Because there is still doubt concerning the direct relationship between $\mathrm{A} \beta$ inhibition of MTT levels and $\mathrm{A} \beta$-induced neuronal death (Shearman et al., 1995; Abe and Kimura, 1996; Liu and Schubert, 1997), the LDH assay was also used to determine actual cell death. Release of the stable constitutive enzyme LDH occurs after cell lysis and therefore gives an accurate estimation of the terminal response of neurons to toxic $\mathrm{A} \beta$. Cortical neuronal cultures that had been treated with $A \beta 25-35$ or $A \beta 1-42$ for $4 \mathrm{~d}$ were assayed for release of $\mathrm{LDH}$. A clear correlation between $\mathrm{A} \beta$ concentration and the level of $\mathrm{LDH}$ release into the culture medium was found (Fig. $1 D, E$ ). The level of cytotoxicity was lower for the LDH assay compared with the MTT assay. This result was expected because of the characteristic ability of $\mathrm{A} \beta$ to rapidly lower the level of MTT reduction in treated cultures without a direct increase in cell death and the loss of membrane integrity required for LDH release (Shearman et al., 1995; Abe and Kimura, 1996; Liu and Schubert, 1997). The LDH assay also did not show a significant difference in $\mathrm{A} \beta$-mediated cell death between $\mathrm{APP}^{-/-}$and $\mathrm{APP}^{+/+}$neurons (Fig. $1 D, E$ ). These results reveal that a lack of normal endogenous APP expression in mouse cortical neurons does not affect the ability of $\mathrm{A} \beta$ to lower neuronal redox activity or induce cell death.

\section{Effect of bFGF on A $\beta$ toxicity in APP ${ }^{-/-}$and APP ${ }^{+/+}$ cortical neurons}

bFGF has been shown to reduce $\mathrm{A} \beta$ toxicity in primary hippocampal cultures (Mattson et al., 1993a) as well as increase APP expression in neurons in vitro (Ohyagi and Tabira. 1993). If these effects were linked, then bFGF treatment of neuronal cultures could result in differential survival of $\mathrm{APP}^{-/-}$and control $\mathrm{APP}^{+/+}$cultures after exposure to $\mathrm{A} \beta$. Treatment of high- and low-density cultures with $10 \mathrm{ng} / \mathrm{ml} \mathrm{bFGF}$ resulted in a significant increase in cell viability after exposure to A $\beta 25-35$ for $4 \mathrm{~d}$ [Fig. $1 A, B,{ }^{*} p<0.05,{ }^{*} p<0.01$ (ANOVA and Newman-Keuls test)]. Interestingly, a difference was not observed between $\mathrm{APP}^{-1-}$ and $\mathrm{APP}^{+/+}$cultures at low or high density, indicating that APP expression is not required for the protective effect of bFGF on $\mathrm{A} \beta$ toxicity in neurons.

\section{A $\beta 25-35$ toxicity in APP $-/-$ and $\mathrm{APP}^{+/+}$cerebellar granule neuron cultures}

To determine how other neuronal cell types are affected by a lack of APP expression, we tested $\mathrm{APP}^{-/-}$and APP ${ }^{+/+}$CGN cultures. A $\beta 25-35$ was added to CGN cultures at day 1 in vitro ( $24 \mathrm{hr}$ after plating) at 5 and $25 \mu \mathrm{M}$. Because CGN cultures do not reveal an immediate drop in MTT reduction, characteristic for $\mathrm{A} \beta$ treated cortical neurons (our unpublished observations), the MTT assay was used as a measure of cell survival rather than cell redox activity alone. Cell viability was determined after exposure for $6 \mathrm{~d}$ instead of $4 \mathrm{~d}$ because of increased resistance to $\mathrm{A} \beta$ induced toxicity in these cultures. As with cortical neuronal cultures, differences were not observed between $\mathrm{APP}^{-1-}$ and 

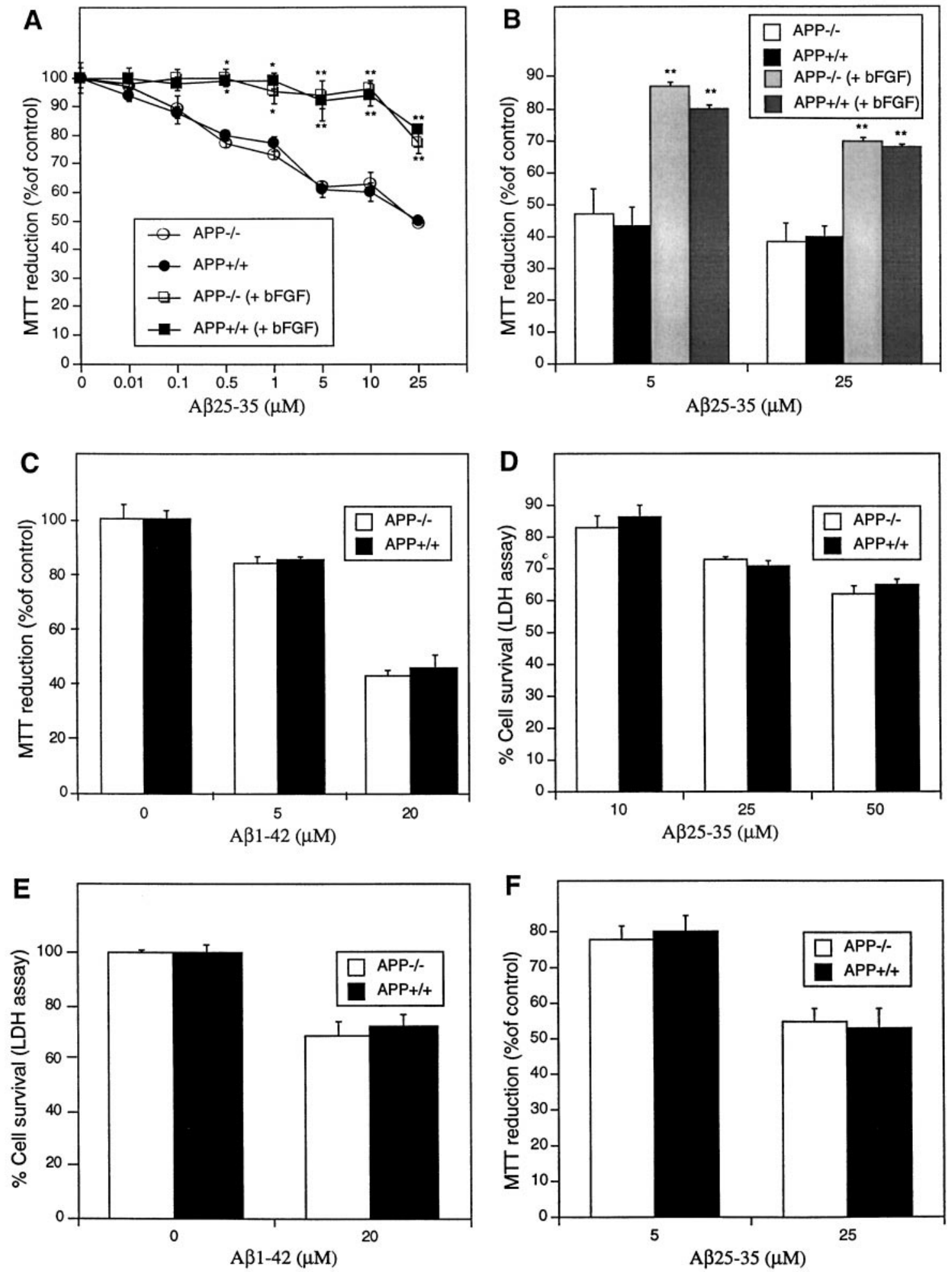

Figure 1. $\mathrm{APP}^{-/-}$and $\mathrm{APP}^{+/+}$cortical neurons do not have differences in susceptibility to $\mathrm{A} \beta 25-35$ or $\mathrm{A} \beta 1-42$ inhibition of MTT reduction. Primary cortical neurons were grown at $(A)$ high density $\left(450,000 \mathrm{cells} / \mathrm{cm}^{2}\right)$ or $(B)$ low density $\left(250,000 \mathrm{cells} / \mathrm{cm}^{2}\right)$ for $3 \mathrm{~d}$ and exposed to $\mathrm{A} \beta 25-35$ for an additional $4 \mathrm{~d}$. No differences between MTT reduction were observed between $\mathrm{APP}^{-/-}$and $\mathrm{APP}^{+/+}$cortical neurons exposed to A $\beta 25-35$ at either density. Treatment of cultures with $10 \mathrm{ng} / \mathrm{ml}$ bFGF (applied concomitantly with $\mathrm{A} \beta$ ) resulted in a significant increase in cell viability as compared with non-bFGF-treated cultures when measured $4 \mathrm{~d}$ after exposure to $\mathrm{A} \beta 25-35 .{ }^{*} p<0.05,{ }^{* *} p<0.01$ : differences in MTT reduction between bFGF and non-bFGF-treated cultures were determined using ANOVA and Newman-Keuls tests. $C$, APP ${ }^{-1-}$ and $\mathrm{APP}^{+/+}$cortical neurons reveal no differences in MTT reduction when treated with $\mathrm{A} \beta 1-42 . D, \mathrm{APP}^{-/-}$and $\mathrm{APP}{ }^{+/+}$cortical neurons have no differences in susceptibility to A $\beta 25-35$-induced cell death as determined using the $\mathrm{LDH}$ assay. $E, \mathrm{APP}^{-/-}$and $\mathrm{APP}^{+/+}$cortical neurons reveal no differences in survival when exposed to A $\beta 1-42$-induced cell death as determined using the $\mathrm{LDH}$ assay. $F, \mathrm{APP}^{-/-}$and $\mathrm{APP}^{+/+}$cerebellar granule neurons reveal no differences in susceptibility to $\mathrm{A} \beta 25-35$ inhibition of MTT reduction. Primary cerebellar neurons were grown for $1 \mathrm{~d}$ and exposed to A $\beta 25-35$ for an additional $6 \mathrm{~d}$. 
$\mathrm{APP}^{+/+} \mathrm{CGN}($ Fig. $1 F$ ). bFGF treatment did not alter the level of $\mathrm{A} \beta$ toxicity in $\mathrm{APP}^{-/-}$and $\mathrm{APP}^{+/+} \mathrm{CGN}$ cultures (data not shown).

\section{Effects of peroxide-associated oxidative stress on cell survival in $\mathrm{APP}^{-/-}$and $\mathrm{APP}^{+/+}$neurons in vitro}

Intracellular peroxide generation can be induced in immature neuronal cultures by exposure to high concentrations (millimolar) of glutamate. This leads to glutathione (GSH) depletion caused by competitive inhibition of cysteine uptake, which is necessary for reduced GSH synthesis (Ratan et al., 1994), resulting in a subsequent increase in intracellular peroxide levels. The role of GSH depletion in this form of glutamate toxicity has been confirmed in our laboratory by preventing toxicity with exogenous GSH (our unpublished observations). This type of oxidative stress is reduced in a B103 cell line transfected with human APP cDNA (Schubert and Behl, 1993), whereas secreted human APP [(hu) sAPP] applied to primary cultures of human and animal cortical neurons results in reduced peroxide generation (Mattson et al., 1993b).

To determine whether APP ${ }^{-/-}$neurons are more susceptible to oxidative stress than wild-type neurons, high concentrations of glutamate were applied to immature cortical cultures ( $3 \mathrm{~d}$ in vitro), and cell viability was determined after $24 \mathrm{hr}$. A significant decrease in cell survival was obtained with at least $5 \mathrm{~mm}$ glutamate (Fig. 2A). Significant differences in toxicity were not observed between $\mathrm{APP}^{-/-}$and $\mathrm{APP}^{+/+}$cultures. Similarly, exposure to exogenous hydrogen peroxide for $24 \mathrm{hr}$ did not affect cell viability of $\mathrm{APP}^{-/-}$compared with $\mathrm{APP}^{+/+}$cultures (Fig. 2B). These results indicate that endogenous APP expression does not significantly reduce peroxide-associated oxidative stress in primary cortical neurons.

\section{Effects of excitotoxicity-mediated oxidative stress on cell survival in APP ${ }^{-/-}$and $\mathrm{APP}^{+/+}$neurons in vitro}

Previous studies have demonstrated that (hu) sAPP applied to primary cultures of human and animal neurons results in increased resistance to glutamate excitotoxicity (Mattson et al., 1993b). To determine whether APP ${ }^{-/-}$neurons have decreased resistance to excitotoxicity, micromolar concentrations of glutamate were added to $\mathrm{APP}^{-/-}$and $\mathrm{APP}^{+/+}$cultures of $\mathrm{CGN}$ and cortical neurons. The CGN neurons were used because of their highly homogeneous nature $(96 \%)$ and well characterized response to excitotoxins (Lindholm et al., 1993). Cortical neurons were used because this cell type has previously been shown to be protected from excitotoxic glutamate by (hu) sAPP (Mattson et al., 1993b). A 30 min exposure to glutamate in 7-d-old cultures of CGN or 14-d-old cultures of cortical neurons resulted in cell death in both cultures as measured by MTT reduction $24 \mathrm{hr}$ after exposure (Fig. 2, $C$ and $D$, respectively). $\mathrm{APP}^{-/-}$and $\mathrm{APP}^{+/+}$ cultures did not differ significantly at any concentration of glutamate used. The findings show that cortical neurons and CGN that do not express APP do not differ in their ability to survive excitotoxic insult.

\section{Effects of superoxide anion-mediated oxidative stress on cell survival in APP $^{-/-}$and APP $^{+/+}$neurons in vitro}

An important form of oxidative stress in neurons is mediated by the superoxide anion free radical (Sagara et al., 1996). To determine whether the antioxidant pathway for superoxide removal (superoxide dismutase pathway) involves APP expression, primary cortical neurons were exposed to increasing concentrations of xanthine oxidase $(\mathrm{XO})$ in the presence of $50 \mu \mathrm{M}$ xanthine, the combination of which results in the generation of superoxide anions (Brown et al., 1996b). Increasing concentrations of XO up to $400 \mathrm{mU} / \mathrm{ml}$ in the medium resulted in increasing cell death in 4- and 6-d-old cultures (Fig. 2E) as measured $24 \mathrm{hr}$ after addition of the enzyme. Little difference in the level of toxicity was observed between cultures at 4 and $6 \mathrm{~d}$ when exposed to 25-100 $\mathrm{mU} / \mathrm{ml} \mathrm{XO}$. At concentrations of 200 and $400 \mathrm{mU} / \mathrm{ml} \mathrm{XO}$, greater toxicity was seen in 4-d-old compared with 6-d-old cultures. Significant differences were not observed in superoxide anion toxicity in $\mathrm{APP}^{-/-}$and $\mathrm{APP}^{+/+}$cultures at either 4 or $6 \mathrm{~d}$ in vitro (Fig. 2E). These results reveal that the level of oxidative stress involving $\mathrm{O}_{2}{ }^{-}$is not significantly affected by expression of APP in cortical neuronal cultures.

\section{Effects of hypoglycemia-mediated oxidative stress on cell survival in APP ${ }^{-/-}$and $\mathrm{APP}^{+/+}$neurons in vitro}

Hypoglycemia can cause increased oxidative stress in neurons through increased generation of reactive oxygen species. Mattson et al. (1993b) have demonstrated a significant protective effect against hypoglycemic-related cell death in neurons exposed to exogenous (hu) sAPP. The role of endogenous APP expression in protection against hypoglycemia was examined by exposing 14-dold cortical neurons from $\mathrm{APP}^{-/-}$and $\mathrm{APP}^{+/+}$to glucose-free Locke's solution for 10,18 , and $24 \mathrm{hr}$. This resulted in a significant and continuous reduction in cell survival over the $24 \mathrm{hr}$ period; again, differences between $\mathrm{APP}^{-/-}$and $\mathrm{APP}^{+/+}$neurons were not observed (Fig. $2 F$ ). These results indicate that neurons capable of expressing endogenous APP have no survival advantage under hypoglycemic conditions.

\section{Effect of $\mathrm{A} \beta 25-35$ and $\mathrm{H}_{2} \mathrm{O}_{2}$ on APP and APLP expression in primary cortical cultures}

As APP is part of a multi-gene family, the similar survival properties of $\mathrm{APP}^{-/-}$and $\mathrm{APP}^{+/+}$neurons in response to $\mathrm{A} \beta$ or oxidative stress may be compensated for by either of the APLPs. To test this hypothesis we exposed $\mathrm{APP}^{-1-}$ and $\mathrm{APP}^{+/+}$neuronal cultures to A $\beta 25-35(10 \mu \mathrm{M})$ or $\mathrm{H}_{2} \mathrm{O}_{2}(25 \mu \mathrm{M})$ for $24 \mathrm{hr}$ and measured APP/APLP expression by quantitative Western blot analysis. The specificities of the APLP2 and APLP1 antibodies are shown in Figure 3. The anti-APLP1 (25104) and anti-APLP2 $(95 / 11)$ antibodies reacted only with their respective recombinant proteins.

As expected, immunoblot analyses of untreated APP ${ }^{-1-}$ cortical neurons did not reveal expression of APP (Fig. 4A). In addition, no increase in basal level expression of APLP1 or APLP2 was observed in APP ${ }^{-/-}$neurons when compared with $\mathrm{APP}^{+/+}$neurons (Fig. $4 A$ ). This is consistent with previous data showing no increase in APLP2 expression in total brain homogenates (Zheng et al., 1995). After a $20 \mathrm{hr}$ exposure to A $\beta 25-35$ $(10 \mu \mathrm{M}), \mathrm{APP}^{+/+}$neurons showed a significant increase in cellassociated APP and APLP2 expression as determined by Western blotting with 22C11 and 95/11, respectively (Fig. 4B,C; Table 2). Although 22C11 cross-reacts with APLP2, differences in molecular weight between APP and APLP2 and a comparison with APP ${ }^{-1-}$ lysates allowed us to demonstrate specific increases in both APLP2 $(110 \mathrm{kDa})$ and APP $(95-105 \mathrm{kDa})$ proteins in $\mathrm{APP}^{+/+}$cultures. Further confirmation of protein specificity was obtained using the APP-specific antibody Ab1-25 (data not shown). Blotting with 95/11 also revealed a significant increase in the $110 \mathrm{kDa}$ APLP2 band in $\mathrm{APP}^{-/-}$cultures exposed to A $\beta 25-35$ (Fig. $4 C$, Table 2). These results indicate that primary cortical neurons respond to $\mathrm{A} \beta$ toxicity by upregulating expres- 
A
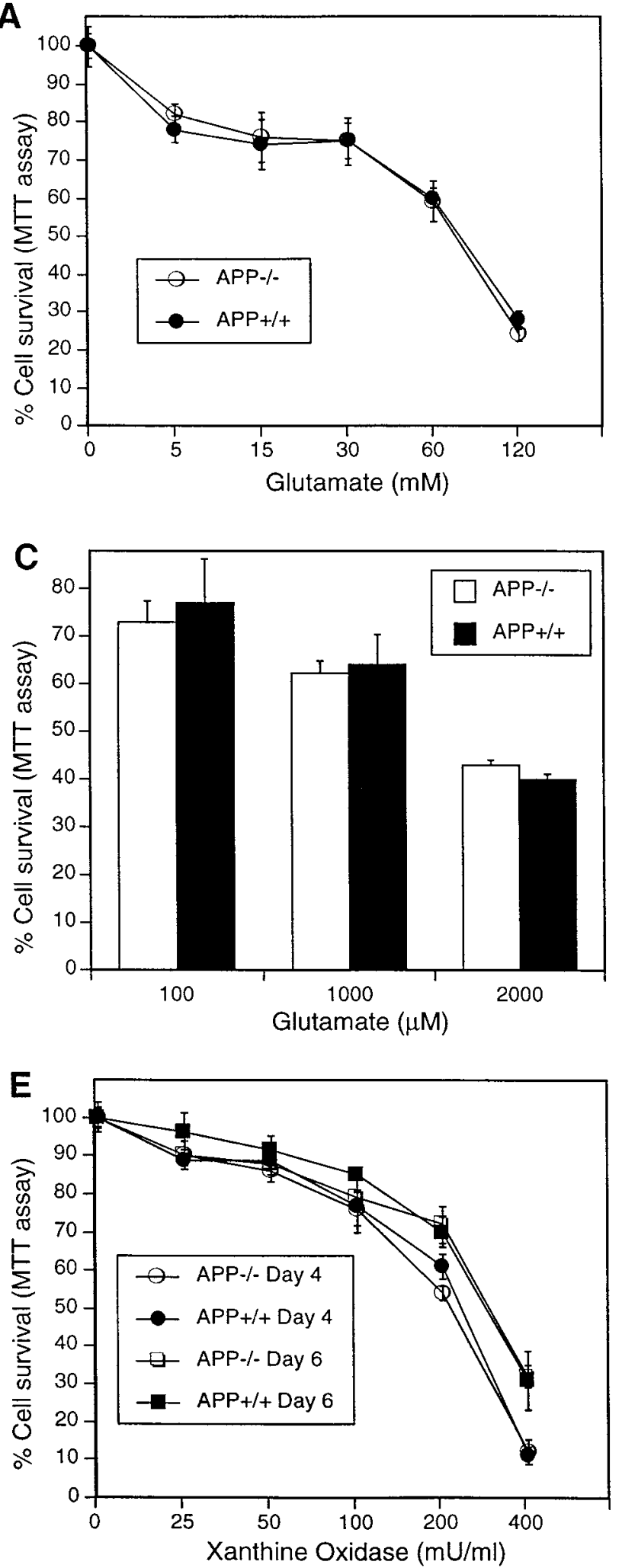

B
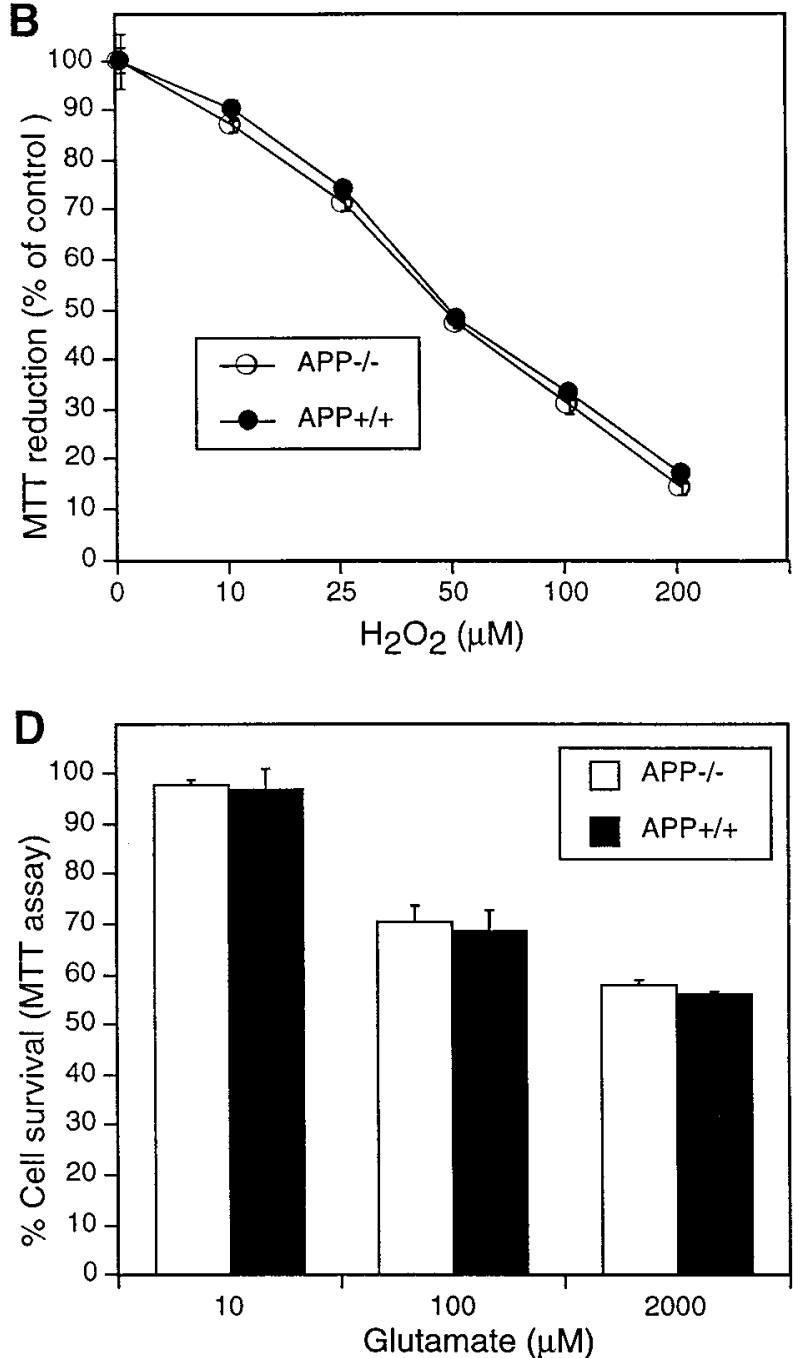

$\mathbf{F}$

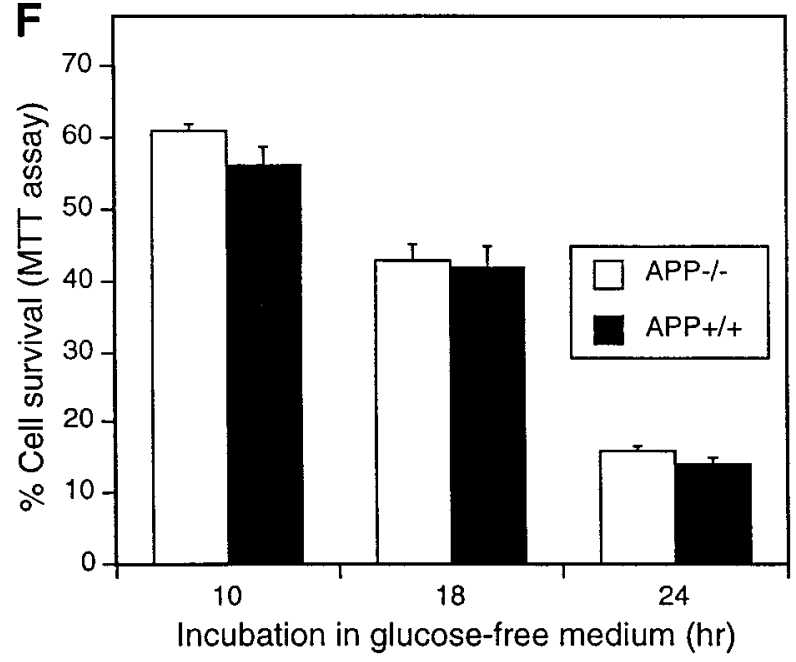

Figure 2. $\mathrm{APP}^{-/-}$and $\mathrm{APP}^{+/+}$neurons do not have differences in susceptibility to intracellular- or extracellular-generated oxidative stress. $A$, Primary cortical neurons were grown for $2 \mathrm{~d}$ and exposed to glutamate for $24 \mathrm{hr}$. B. Primary cortical cultures were grown for $4 \mathrm{~d}$ and then exposed to $\mathrm{H}_{2} \mathrm{O}_{2}$ for $24 \mathrm{hr}$. $C$, Primary cerebellar granule neurons were grown for $7 \mathrm{~d}$ and then exposed to glutamate for 30 min. $D$, Primary cortical cultures were grown for $14 \mathrm{~d}$ and then exposed to glutamate for $30 \mathrm{~min}$. Cell viability was determined $24 \mathrm{hr}$ later. E. Primary cortical neurons were exposed to increasing concentrations of xanthine oxidase and $50 \mu \mathrm{M}$ xanthine for $24 \mathrm{hr}$ at either 4 or $6 \mathrm{~d}$ in vitro. $F$, Primary cortical neurons were grown for $14 \mathrm{~d}$ before incubation in glucose-free Locke's media. Cell viability was determined after the given incubation period. 


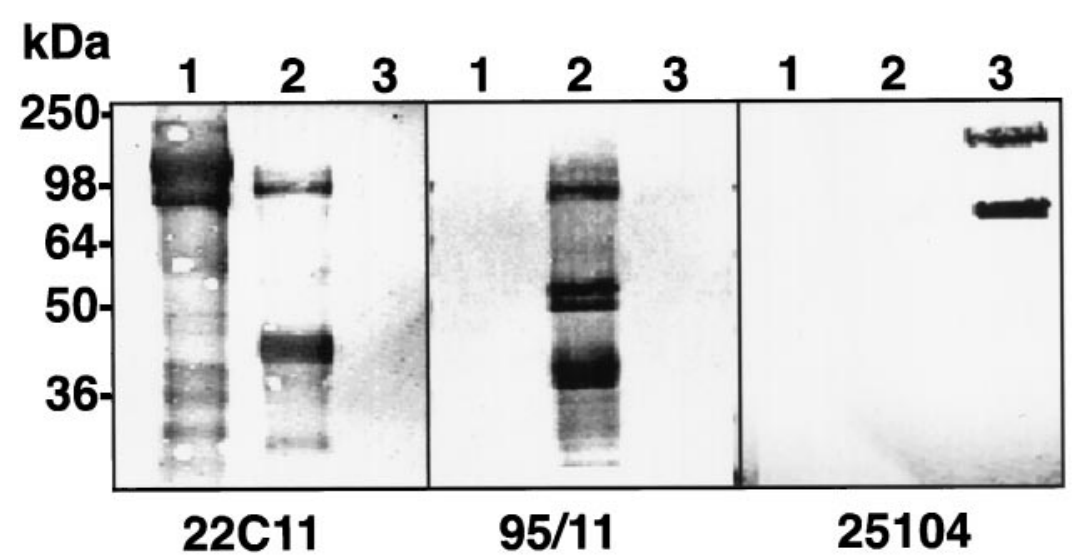

Figure 3. Characterization of the specificity of the APLP2 and APLP1 antibodies. Western blots of recombinant sAPP751 (lane 1), sAPLP2 (lane 2), and sAPLP1 (lane 3) probed with 22C11 (anti-APP/APLP2, 1:2000), 95/11 (antiAPLP2, 1:1000), or 25104 (anti-APLP1, 1:1000). The lower bands correspond to breakdown products as described previously (Henry et al., 1997). The position of the molecular weight markers is indicated on the left. sion of both APP and APLP2. Immunoblotting analysis with anti-APLP1 antibody did not reveal any significant increase in this protein in $\mathrm{APP}^{+/+}$or $\mathrm{APP}^{-/-}$cultures exposed to $\mathrm{A} \beta 25-35$ (Fig. $4 D$, Table 2). In contrast to the effect of $\mathrm{A} \beta 25-35$, the treatment of $\mathrm{APP}^{+/+}$and $\mathrm{APP}^{-/-}$cortical cultures with $25 \mu \mathrm{M}$ $\mathrm{H}_{2} \mathrm{O}_{2}$ for $24 \mathrm{hr}$ resulted in no significant change in the expression levels of APP or APLP (Fig. $4 E-G$ ). A similar result was also obtained when 3-d-old cultures were exposed to glutamate (15 $\mathrm{mm}$ ) for $24 \mathrm{hr}$ (data not shown). This indicates that the basal levels of APLP in the APP ${ }^{-/-}$cultures provide a similar level of protection to APP and APLP in $\mathrm{APP}^{+/+}$cultures.

\section{DISCUSSION}

The aim of this work was to investigate the neuroprotective role of endogenously expressed APP in the CNS. It has been shown that treatment of primary neurons with secreted forms of APP (Mattson et al., 1993b; Goodman and Mattson, 1994) or transfection of cell lines and mice with (hu)APP cDNA (Schubert and Behl, 1993; Mucke et al., 1996) results in protection against oxidative toxicity induced by the $\mathrm{A} \beta$ peptide, glutamate excitotoxicity, and hypoglycemia. This increased survival may reflect a heightened resistance to oxidative stress. Although these findings support a neuroprotective activity for APP, the role of endogenous neuronal APP in neuroprotection has not been assessed. We used APP knock-out primary neurons to test the role of endogenous APP because they avoid the problems associated with antisense procedures.

This study clearly demonstrates that endogenous APP expression does not alter the survival of primary cortical or cerebellar neurons in response to $\mathrm{A} \beta$-mediated toxicity or oxidative stress in vitro. We found that the absence of APP expression had no effect on neuronal viability under basal conditions (Table 1), suggesting that the neurotrophic activity of APP is not essential for cortical or cerebellar neuronal growth in vitro. This differs slightly from a report on survival of hippocampal neurons cultured from APP $^{-/-}$mice. Perez et al. (1997) observed a small but significant reduction in viability in $\mathrm{APP}^{-/-}$as compared with $\mathrm{APP}^{+/+}$ hippocampal neurons in primary culture. The results from our study may simply reflect differences between cell types (cortical vs hippocampal), media, cell densities, or the effect of astrocyteconditioned media. There was no observable increase in the basal levels of APLP1 and APLP2 expression in APP ${ }^{-/-}$neurons in our study, indicating that under normal growth conditions in vitro, the absence of APP does not require the compensatory increased expression of an APLP. We evaluated the survival of $\mathrm{APP}^{-1-}$ and $\mathrm{APP}^{+/+}$neurons under neurotoxic conditions by exposing them to a range of endogenously and exogenously generated oxidative stresses. In all cases, differences in cell survival were not observed between the APP ${ }^{-/-}$and $\mathrm{APP}^{+/+}$neurons. However, changes in APP and APLP expression were found after exposure to $\mathrm{A} \beta$ but not to $\mathrm{H}_{2} \mathrm{O}_{2}$. $\mathrm{A} \beta$ treatment caused increased expression of APLP2 and APP in APP ${ }^{+/+}$neurons and APLP2 in APP ${ }^{-/-}$ neurons.

Our data demonstrating a similarity between the $\mathrm{APP}^{-/-}$and $\mathrm{APP}^{+/+}$neurons do not support a neuroprotective function for endogenous APP in vitro. It is possible that the level of endogenous APP expression and secretion in primary neuronal cultures is too low to influence the level of neuroprotection against oxidative stress. If so, the absence of APP in APP ${ }^{-1-}$ neurons would not be expected to have any effect. The level of APP expression in transgenic mice is an important factor in determining the degree of neuroprotection against excitotoxic insult (Mucke et al., 1996). Although the specific level of sAPP in primary neuronal cultures has not been reported, our immunoblotting data and the study by Hung et al. (1992) show that primary neuronal cultures express readily detectable levels of APP (Fig. $4 B$ ). It is therefore unlikely that the level of APP expression is too low to induce a measurable neuroprotective effect.

The similarity between the $\mathrm{APP}^{-/-}$and $\mathrm{APP}^{+/+}$neurons may reflect species-dependent sequence variations between human and mouse APP. The effect of these sequence differences on neuroprotection is unknown because all previous studies have used human APP. The high homology between the coding regions $(97 \%)$ and the 5 ' regulatory regions of human and mouse APP (De Strooper et al., 1991; Chernak, 1993) suggests a conserved function between species and is therefore also an unlikely explanation. However, it has been proposed that the A $\beta 1-16$ sequence is important for neuroprotection, possibly through heparin binding. Interestingly, the three differences between the mouse and human $\mathrm{A} \beta$ sequences are all contained within $\mathrm{A} \beta 1-$ 16, including the histidine to arginine substitution at position 13 that may be required for heparin binding (Brunden et al., 1993).

We speculate that $\mathrm{APP}^{-/-}$and $\mathrm{APP}^{+/+}$neurons do not display any differences because APLP expression is able to compensate for the absence of APP. This model would support the existing studies describing the neuroprotective activity of APP but indicates that this function could also be shared by the APLP molecules. There is considerable sequence homology and conservation of putative functional motifs and domains between APP and the APLP (Paliga et al., 1997). These similarities suggest the APLPs could share and/or compensate for the function of APP, thus 
A

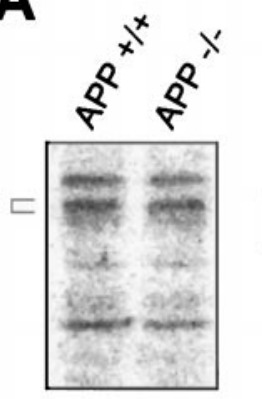

anti-APLP2

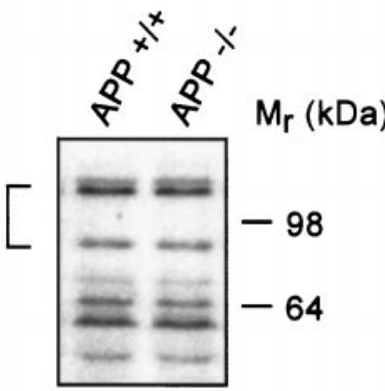

anti-APLP1

B

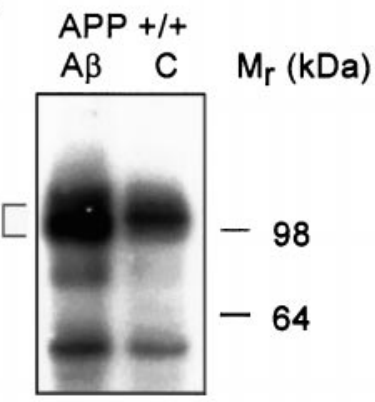

anti-APP

D

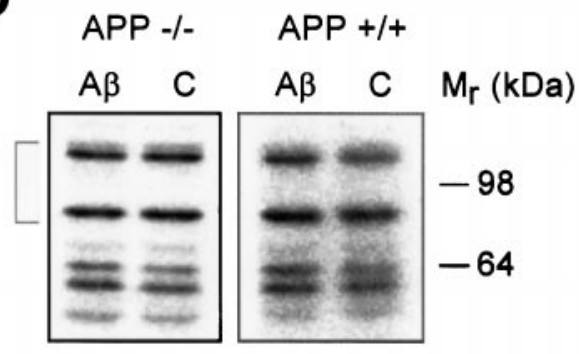

anti-APLP1

F

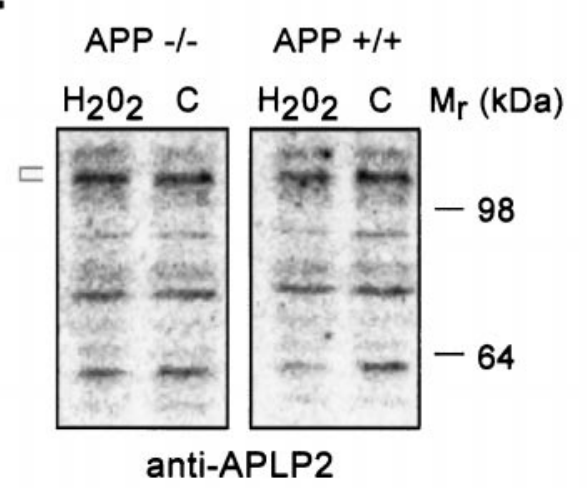

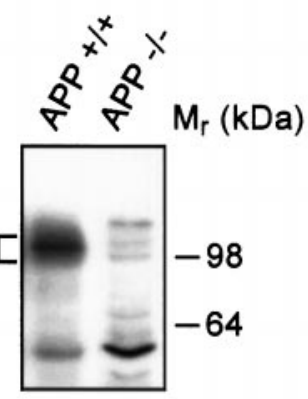

anti-APP

C

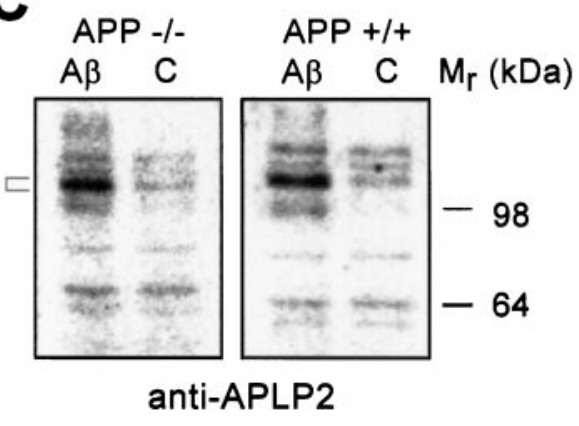

E

EPP +/+

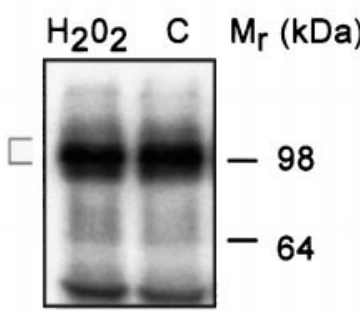

anti-APP

G

$$
\text { APP -/- } \quad \text { APP +/+ }
$$

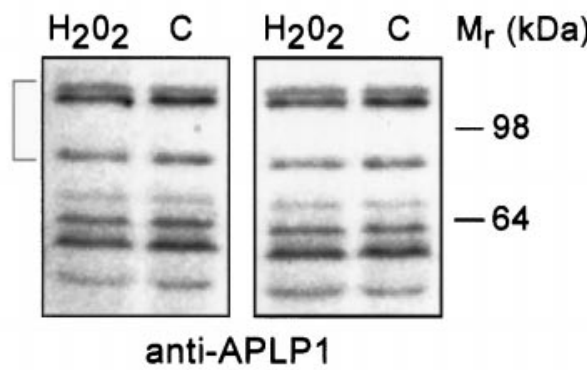

Figure 4. Quantitative immunoblotting of cell-associated APP, APLP1, and APLP2 in neurons exposed to A $\beta 25-35$ and $\mathrm{H}_{2} \mathrm{O}_{2}$. Primary cortical neurons were grown for $2 \mathrm{~d}$ and then exposed to either $10 \mu \mathrm{M} \mathrm{A} \beta 25-35(\mathrm{~A} \beta)$ or $25 \mu \mathrm{M} \mathrm{H} \mathrm{H}_{2} \mathrm{O}_{2}$, or were untreated [control $(C)$ ] for 24 hr. The antibodies are anti-APP/APLP2 (22C11, 1:2000), anti-APLP2 (95/11, 1:1000), or anti-APLP1 (25104, 1:1000). The brackets correspond to the proteins described in Results and their molecular weights are as follows: anti-APP (95-105), anti-APLP1 (87 and 126), and anti-APLP2 (110 kDa). The position of the molecular weight markers is indicated on the right-hand side. A, Analysis of APLP2, APLP1, and APP expression under basal conditions. B, Analysis of APP expression detected in A $\beta 25-35$-treated APP ${ }^{+/+}$cultures. $C$, Analysis of APLP2 expression in A $\beta 25-35$-treated APP ${ }^{-/-}$and APP ${ }^{+/+}$neurons shows a significant increase in APLP2 expression in both $\mathrm{APP}^{-1-}$ and $\mathrm{APP}^{+/+}$neurons exposed to A $\beta$. $D$, Analysis of APLP1 expression in $\mathrm{A} \beta 25-35$-treated $\mathrm{APP}^{-/-}$or APP ${ }^{+/+}$neurons. E, Analysis of APP expression in $\mathrm{APP}^{+/+}$neurons in response to $\mathrm{H}_{2} \mathrm{O}_{2}$. F, Analysis of APLP2 expression in $\mathrm{H}_{2} \mathrm{O}_{2}$-treated $\mathrm{APP}^{-/-}$and $\mathrm{APP}{ }^{+/+}$neurons. $G$, Analysis of APLP1 expression in $\mathrm{H}_{2} \mathrm{O}_{2}$-treated APP ${ }^{-/-}$and $\mathrm{APP}{ }^{+/+}$neurons. 
Table 2. Quantitation of the immunoblot data on cell-associated APP, APLP1, and APLP2 expression after A $\beta 25-35$ treatment as shown in Figure $4 B-D$

\begin{tabular}{llcl}
$\begin{array}{l}M_{\mathrm{r}} \text { range } \\
(\mathrm{kDa})\end{array}$ & Antibody & $\begin{array}{l}\text { APP } \\
\text { expression }\end{array}$ & $\begin{array}{l}\text { \% Increase in protein } \\
\text { expression compared } \\
\text { with untreated } \\
\text { control }\end{array}$ \\
\hline $95-105$ & 22C11 (APP) & + & $68 \pm 1.4$ \\
110 & $95 / 11$ (APLP2) & - & $69 \pm 3.4$ \\
& & + & $81 \pm 3.1$ \\
$115-135$ & 95/11 (APLP2) & - & $34 \pm 4.9$ \\
& & + & $10 \pm 0.2$ \\
87 and 126 & 25104 (APLP1) & - & $8 \pm 0.7$ \\
& & + & $4 \pm 2.1$
\end{tabular}

The data were derived from quantitative analysis of ${ }^{125}$ I-protein-A-labeled blots with a Fujix 1000 Phosphorimager and MacBas1 software. The percentage increase corresponds to the amount of protein detected in cultures treated with A $\beta 25-35$ compared with untreated cultures.

reflecting a redundancy in the APP gene family. This is supported by studies in which APP, APLP1, and APLP2 single knock-out mice have been shown to survive with minor neurological dysfunction (Zheng et al., 1995; Muller et al., 1997; von Koch et al., 1997). However, APP/APLP2 double knock-outs are a lethal combination resulting in death during embryonic to early postnatal development (von Koch et al., 1997). This suggests that although early cerebral development may not be severely impaired by a loss of either APP or APLP expression, cells cannot compensate for a simultaneous loss of both. The APLP could be compensating for APP by binding to and stimulating the APP receptor. Alternatively, APLP could be acting as a receptor to bind the APP ligand and transmit the appropriate signal. However, the putative compensatory role of APLP remains to be tested.

The finding that cell-associated APP and APLP2 expression is increased after exposure to $\mathrm{A} \beta$ is consistent with previous reports (Cribbs et al., 1995; Saporito-Irwin et al., 1997; Schmitt et al., 1997). The increased level of cell -associated protein may be attributable, at least in part, to decreased secretion because $40 \%$ less sAPP was detected in the media of $\mathrm{A} \beta$-treated cultures (data not shown). This is supported by Schmitt et al. (1997) who reported that increases in cellular APP expression induced by A $\beta 25-35$ were caused by decreases in APP secretion. APP and APLP2 have similar expression and secretory pathways (Nitsch et al., 1992; Webster et al., 1995). Interestingly, no change was seen in sAPLP2 levels after $\mathrm{A} \beta$ treatment (data not shown). This would indicate that $A \beta$ can also induce increased expression of APLP2, and possibly APP, and that $\mathrm{A} \beta$ may have differential effects on some aspects of APP and APLP2 expression and processing. No change in APLP1 expression was detected after exposure to $\mathrm{A} \beta$, and this may reflect the lower homology of APLP1 with APP and APLP2. This data would indicate that APLP2 expression, rather than APLP1, may be responsible for compensatory activity in APP ${ }^{-/-}$cells. To clarify this issue, the neuroprotective activity of APLP2 and APLP1 needs to be determined. In addition, the susceptibility of neurons from APLP1 and APLP2 single knock-outs and APP/APLP1, APP/ APLP2, and APLP1/APLP2 double knock-outs to oxidative stress also needs to be investigated.

Our finding that APP and APLP expression levels remain unaltered in $\mathrm{H}_{2} \mathrm{O}_{2}$ and glutamate-treated cultures is important because it suggests that $\mathrm{A} \beta$-induced toxicity is distinct from general oxidative stress and that $\mathrm{A} \beta$ increases APP/APLP2 expression through a nonoxidative stress-related pathway. This could be because $\mathrm{A} \beta$ operates via an $\mathrm{A} \beta$-receptor (Yan et al., 1996, 1997), which results in either localized oxidative stress or activation of a specific cell-signaling pathway or both. In contrast, $\mathrm{H}_{2} \mathrm{O}_{2}$ and glutamate produce pan-cellular oxidative stress, which does not increase APP/APLP expression. It is unlikely that the level of $\mathrm{H}_{2} \mathrm{O}_{2}$ or glutamate exposure was too low to induce APP/APLP expression because the level of toxicity obtained was similar to that induced by $\mathrm{A} \beta$.

It has been suggested that toxic, amyloidogenic peptides may share a common toxic mechanism (Ridley and Baker, 1993). Our data would suggest that the mechanism of $\mathrm{A} \beta$-toxicity is distinct from the amyloidogenic prion protein-derived peptide PrP106126 (Brown et al., 1996a). The PrP106-126 peptide requires expression of normal cellular prion protein (the parent molecule) to induce toxicity in neurons in vitro (Brown et al., 1996a). In contrast, our results show that $\mathrm{A} \beta$ does not require the presence of the normal parent molecule (APP) to induce neuronal toxicity (other than as a source of $\mathrm{A} \beta$ in vivo). This suggests that although A $\beta$ may induce a positive feedback effect on APP processing leading to increased $\mathrm{A} \beta$ formation and aberrant APP metabolism (Cribbs et al., 1995), these factors do not contribute to the short-term neuronal loss seen in vitro. The effect of increased APP expression may result, however, in changes to neuronal survival in the longer term. An alternative, and exciting, explanation is that if the APLP molecules represent functional homologs of APP then the $\mathrm{A} \beta$ peptide could act through an APLP, and in particular APLP2. This would suggest that APP/APLP double knock-out neurons would be refractory to $\mathrm{A} \beta$ toxicity and hence mimic the prion- $\mathrm{PrP}^{\mathrm{c}}$ model.

If APP is involved in neuroprotection against $\mathrm{A} \beta$ and oxidative stress in vivo, then any perturbations to APP metabolism such as those occurring in $\mathrm{AD}$ may not only result in increased $\mathrm{A} \beta$ deposition but may also reduce neuroprotection (Mattson et al., 1993b). If the APLP molecules, in particular APLP2, have a neuroprotective function reflecting that seen with SAPP, then changes to APLP protein metabolism may also result in decreased neuronal resistance to oxidative insults or $\mathrm{A} \beta$. A neuroprotective role for APLP may have important implications for Alzheimer's disease because therapeutic treatments specifically aimed at increasing APLP expression may provide a means of increasing neuroprotection without directly contributing to $\mathrm{A} \beta$ deposition. This may have the added benefit of replacing some of the functions that are lost because of aberrant APP metabolism, such as dendritic growth.

\section{REFERENCES}

Abe K, Kimura $\mathrm{H}$ (1996) Amyloid $\beta$ toxicity consists of a $\mathrm{Ca}^{2+}$. independent early phase and $\mathrm{a} \mathrm{Ca}^{2+}$-dependent late phase. J Neurochem 67:2074-2078.

Barger SW, Fiscus RR, Ruth P, Hofmann F, Mattson MP (1995) Role of cyclic GMP in the regulation of neuronal calcium and survival by secreted forms of $\beta$-amyloid precursor. J Neurochem 64:2087-2096.

Brown DR, Schmidt B, Kretzschmar HA (1996a) A neurotoxic prion protein fragment enhances proliferation of microglia but not astrocytes in culture. Glia 18:59-67.

Brown DR, Schmidt B, Kretzschmar HA (1996b) Role of microglia and host prion protein in neurotoxicity of a prion protein fragment. Nature 380:345-347.

Brunden KR, Richter-Cook NJ, Chaturvedi N, Frederickson RCA (1993) $\mathrm{pH}$-dependent binding of synthetic $\beta$-amyloid peptides to glycosaminoglycans. J Neurochem 61:2147-2154. 
Chernak JM (1993) Structural features of the 5' upstream regulatory region of the gene encoding rat amyloid precursor protein. Gene 133:255-260.

Cribbs DH, Davis-Salinas J, Cotman CW, Van Nostrand WE (1995) A $\beta$ induces increased expression and processing of amyloid precursor protein in cortical neurons. Alzheimer's Res 1:197-200.

De Strooper B, Van Leuven F, Van Den Berghe H (1991) The amyloid $\beta$ protein precursor or proteinase nexin II from mouse is closer related to its human homolog than previously reported. Biochim Biophys Acta 1129:141-143.

Glenner GG, Wong CW (1984) Alzheimer's disease and Down's syndrome: sharing of a unique cerebrovascular amyloid fibril protein. Biochem Biophys Res Commun 122:1131-1135.

Goodman Y, Mattson MP (1994) Secreted forms of $\beta$-amyloid precursor protein protect hippocampal neurons against amyloid $\beta$-peptideinduced oxidative injury. Exp Neurol 128:1-12.

Henry A, Masters CL, Beyreuther K, Cappai R (1997) Expression of the ectodomains of the human amyloid precursor protein in Pichia pastoris: analysis of culture conditions, purification, and characterization. Protein Expr Purif 10:283-291.

Hung AY, Koo EH, Haass C, Selkoe DJ (1992) Increased expression of $\beta$-amyloid precursor protein during neuronal differentiation is not accompanied by secretory cleavage. Proc Natl Acad Sci USA 89:9439-9443.

Kang J, Lemaire H, Unterbeck A, Salbaum JM, Masters CL, Grzeschik K, Multhaup G, Beyreuther K, Müller-Hill B (1987) The precursor of Alzheimer's disease amyloid A4 protein resembles a cell-surface receptor. Nature 325:733-736.

Koh J, Yang LL, Cotman CW (1990) $\beta$-Amyloid protein increases the vulnerability of cultured cortical neurons to excitotoxic damage. Brain Res 533:315-320.

Koo EH, Sisodia SS, Archer DR, Martin LJ, Weidemann A, Beyreuther K, Fischer P, Masters CL, Price DL (1990) Precursor of amyloid protein in Alzheimer disease undergoes fast anterograde axonal transport. Proc Natl Acad Sci USA 87:1561-1565.

Lindholm D, Dechant G, Heisenberg C, Thoenen H (1993) Brainderived neurotrophic factor is a survival factor for cultured rat cerebellar granule neurons and protects them against glutamate-induced neurotoxicity. Eur J Neurosci 5:1455-1464.

Liu Y, Schubert D (1997) Cytotoxic amyloid peptides inhibit cellular 3-(4,5-dimethylthiazol-2-yl)-2,5-diphenyltetrazolium bromide (MTT) reduction by enhancing MTT formazan exocytosis. J Neurochem 69:2285-2293.

Lockhart BP, Benicourt C, Junien JL, Privat A (1994) Inhibitors of free radical formation fail to attenuate direct $\beta$-amyloid25-35 peptidemediated neurotoxicity in rat hippocampal cultures. J Neurosci Res 39:494-505.

Masters CL, Simms G, Weinman NA, Multhaup G, McDonald BL, Beyreuther K (1985) Amyloid plaque core protein in Alzheimer disease and Down syndrome. Proc Natl Acad Sci USA 82:4245-4249.

Mattson MP (1997) Cellular actions of beta-amyloid precursor protein and its soluble and fibrillogenic derivatives. Physiol Rev 77:1081-1132.

Mattson MP, Barger SW, Cheng B, Lieberburg I, Smith-Swintosky VL, Rydel RE (1993a) $\beta$-Amyloid precursor protein metabolites and loss of neuronal $\mathrm{Ca}^{2+}$ homeostasis in Alzheimer's disease. Trends Neurosci 16:409-414.

Mattson MP, Cheng B, Culwell AR, Esch FS, Lieberburg I, Rydel RE (1993b) Evidence for excitoprotective and intraneuronal calciumregulating roles for secreted forms of the $\beta$-amyloid precursor protein. Neuron 10:243-254.

Milward E, Papadopoulos R, Fuller SJ, Moir RD, Small D, Beyreuther K, Masters CL (1992) The amyloid protein precursor of Alzheimer's disease is a mediator of the effects of nerve growth factor on neurite outgrowth. Neuron 9:129-137.

Mucke L, Abraham CR, Masliah E (1996) Neurotrophic and neuroprotective effects of hAPP in transgenic mice. Ann NY Acad Sci 777:82-88.

Muller U, Gajic V, Hainsellner J, Aguzzi A, Herms J, Tremml P, Wolfer D, Lipp HP (1997) Transgenic models to define the physiological role of proteins of the APP-family. Soc Neurosci Abstr 23:1874.

Nakamura Y, Takeda M, Niigawa H, Hariguchi S, Nishimura T (1992) Amyloid $\beta$-protein precursor deposition in rat hippocampus lesioned by ibotenic acid injection. Neurosci Lett 136:95-98.

Nitsch RM, Slack BE, Wurtman RJ, Growdon JH (1992) Release of
Alzheimer amyloid precursor derivatives stimulated by activation of muscarinic acetylcholine receptors. Science 258:304-307.

Ohyagi Y, Tabira T (1993) Effect of growth factors and cytokines on expression of amyloid $\beta$ protein precursor mRNAs in cultured neural cells. Mol Brain Res 18:127-132.

Paliga K, Peraus G, Kreger S, Dürrwang U, Hesse L, Multhaup G, Masters CL, Beyreuther K, Weidemann A (1997) Human amyloid precursor-like protein 1 cDNA cloning, ectopic expression in COS-7 cells and identification of soluble forms in the cerebrospinal fluid. Eur J Biochem 250:354-363.

Perez RG, Zheng H, Van der Ploeg LHT, Koo EH (1997) The $\beta$-amyloid precursor protein of Alzheimer's disease enhances neuron viability and modulates neuronal polarity. J Neurosci 17:9407-9414.

Pike CJ, Burdick D, Walenciwicz AJ, Glabe CG, Cotman CW (1993) Neurodegeneration induced by $\beta$-amyloid peptides in vitro: the role of peptide assembly state. J Neurosci 13:1676-1687.

Ratan RR, Murphy TH, Baraban JM (1994) Oxidative stress induces apoptosis in embryonic cortical neurons. J Neurochem 62:376-379.

Ridley RM, Baker HF (1993) Prion protein: a different concept of replication. Trends Neurosci 16:425-426.

Roher AE, Ball MJ, Bhave SV, Wakade AR (1991) $\beta$-amyloid from Alzheimer disease brains inhibits sprouting and survival of sympathetic neurons. Biochem Biophys Res Commun 174:572-579.

Sagara Y, Dargusch R, Klier FG, Schubert D, Behl C (1996) Increased antioxidant enzyme activity in amyloid $\beta$ protein-resistant cells. J Neurosci 16:497-505.

Salvietti N, Cattaneo E, Govoni S, Racchi M (1996) Changes in $\beta$-amyloid precursor protein secretion associated with the proliferative status of CNS derived progenitor cells. Neurosci Lett 212:199-203.

Sandbrink R, Masters CL, Beyreuther K (1994) $\beta A 4$-amyloid protein precursor mRNA isoforms without exon 15 are ubiquitously expressed in rat tissues including brain, but not in neurons. $\mathrm{J}$ Biol Chem 269:1510-1517.

Saporito-Irwin SM, Thinakaran G, Ruffini L, Sisodia SS, Van Nostrand WE (1997) Amyloid $\beta$-protein stimulates parallel increases in cellular levels of its precursor and amyloid precursor-like protein 2 (APLP2) in human cerebrovascular smooth muscle cells. Int J Exp Clin Invest $4: 54-60$.

Schmitt TL, Steiner E, Trieb K, Grubeck-Loebenstein B (1997) Amyloid beta-protein (25-35) increases cellular APP and inhibits the secretion of APPs in human extraneuronal cells. Exp Cell Res 234:336-340.

Schubert D, Behl C (1993) The expression of amyloid beta protein precursor protects nerve cells from beta-amyloid and glutamate toxicity and alters their interaction with the extracellular matrix. Brain Res 629:275-282.

Schubert D, Jin LW, Saitoh T, Cole G (1989) The regulation of amyloid $\beta$ protein precursor secretion and its modulatory role in cell adhesion. Neuron 3:689-694.

Shearman MS, Hawtin SR, Tailor VJ (1995) The intracellular component of cellular 3-(4,5-dimethylthiazol-2-yl)-2,5-diphenyltetrazolium bromide (MTT) reduction is specifically inhibited by $\beta$-amyloid peptides. J Neurochem 65:218-227.

Slunt HH, Thinakaran G, Von Koch C, Lo ACY, Tanzi RE, Sisodia SS (1994) Expression of a ubiquitous, cross-reactive homologue of the mouse $\beta$-amyloid precursor protein (APP). J Biol Chem 269:2637-2644.

Sprecher CA, Grant FJ, Grimm G, O'Hara PJ, Norris F, Norris K, Foster DC (1993) Molecular cloning of the cDNA for a human amyloid precursor protein homolog: evidence for a multigene family. Biochemistry 32:4481-4486.

Tanzi RE, McClatchey AI, Lamperti ED, Villa-Komaroff L, Gusella JF, Neve RL (1988) Protease inhibitor domain encoded by an amyloid protein precursor mRNA associated with Alzheimer's disease. Nature 331:528-530.

von Koch CS, Zheng H, Chen H, Trumbauer M, Thinakaran G, van der Ploeg LHT, Price DL, Sisodia SS (1997) Generation of APLP2 KO mice and early postnatal lethality in APLP2/APP double KO mice. Neurobiol Aging 18:661-669.

Wasco W, Bupp K, Magendantz M, Gusella JF, Tanzi RE, Solomon F (1992) Identification of a mouse brain cDNA that encodes a protein related to the Alzheimer disease-associated amyloid $\beta$ protein precursor. Proc Natl Acad Sci USA 89:10758-10762.

Wasco W, Gurubhagavatula S, Paradis MD, Romano DM, Sisodia SS, Hyman BT, Neve RL, Tanzi RE (1993) Isolation and characterization 
of APLP2 encoding a homologue of the Alzheimer's associated amyloid $\beta$ protein precursor. Nat Genet 5:95-100.

Webster MT, Groome N, Francis PT, Pearce BR, Sherriff FE, Thinakaran G, Felsenstein KM, Wasco W, Tanzi RE, Bowen DM (1995) A novel protein, amyloid precursor-like protein 2, is present in human brain, cerebrospinal fluid and conditioned media. Biochem J 310:95-99.

Yan SD, Chen X, Fu J, Chen M, Zhu HJ, Roher A, Slattery T, Zhao L, Nagashima M, Morser J, Migheli A, Nawroth P, Stern D, Schmidt AM (1996) RAGE and amyloid- $\beta$ peptide neurotoxicity in Alzheimer's disease. Nature 382:685-691.

Yan SD, Fu J, Soto C, Chen X, Zhu HJ, Almohanna F, Collison K, Zhu AP, Stern E, Saido T, Tohyama M, Ogawa S, Roher A, Stern D (1997) An intracellular protein that binds amyloid-beta peptide and mediates neurotoxicity in Alzheimer's disease. Nature 389:689-695.
Yankner BA, Dawes LR, Fisher S, Villa-Komaroff L, Oster-Granite ML, Neve RL (1989) Neurotoxicity of a fragment of the amyloid precursor associated with Alzheimer's disease. Science 245:417-420.

Yankner BA, Duffy LK, Kirschner DA (1990) Neurotrophic and neurotoxic effects of amyloid $\beta$ protein: reversal by tachykinin neuropeptides. Science 250:279-282.

Zhang F, Eckman C, Younkin S, Hsiao KK, Iadecola C (1997) Increased susceptibility to ischemic brain damage in transgenic mice overexpressing the amyloid precursor protein. J Neurosci 17:7655-7661.

Zheng H, Jiang MH, Trumbauer ME, Sirinathsinghji DJS, Hopkins R, Smith DW, Heavens RP, Dawson GR, Boyce S, Conner MW, Stevens KA, Slunt HH, Sisodia SS, Chen HY, Van der Ploeg LHT (1995) $\beta$-amyloid precursor protein-deficient mice show reactive gliosis and decreased locomotor activity. Cell 81:525-531. 